\title{
母子健康手帳の公衆衛生学的意義と
}

\section{その問 題}

\author{
How to use a Booklet of Mother and Child Health
}

岡山大学医学部衛生学教室 (主任 大平昌彦教授)

和気健 三

Kenzo Wake

Department of Hygiene, Okayama University Medical School, Okayama

\begin{abstract}
A Booklet of Mother and Child Health which is provided by the Maternal and Child Health Law, to every pregnant mother for recording health histories through pregnancy to school entrance, might play a very important role in the field of public health practice, when it is used more practically.

Recently, there are various kinds of health booklets for recording one's health history such as a booklet for school children and students and for chronic diseases in the fields of school and occupational health.

The author discussed records in the booklet utilizing the mother's memory with regard to health histories, in order to establish a more useful method of application to maternal and child health practice.

The results are as follows.

1) Most mothers still keep their booklets even when their children are in school.

2) The columns for delivery in the booklet are filled by doctors or midwives, however, those for mothers' voluntary recording are almost blank.

3) The author demonstrated interesting evidence that the more often mothers have opportunities to use the booklets, the more carefully they keep them.

4) The rate of filling in columns is related not only to mothers' but also to doctors', public health nurses' and midwives' understanding of the significance of the booklets.

5) He pointed out that mothers' memories of their children's health histories, though including important episodes, are not so clear.

6) He also pointed out that mothers' evaluations of their children's developments are not so exact, especially, in cases when the mothers evaluate children developing poorly.
\end{abstract}

I. 緒 論

わが国の戦前における母子保健に対する行政上の施策 は救貧の範囲を出でず, 戦後ようやく昭和 23 年に到って 児童福祉法の施行をみて，乙れに基づく母子保健対策が 定められて，妊産婦乳幼児に対する全国的規模による保 健対策の方針が初めて指示された。さらに，昭和40年に は従来の児童福祉中心から，広く母性小児を対象とした 母子保健に関する単独立法として母子保健法が制定さ れ，現在はこれに基づいて母子保健関する諸施策が行 なわれている(1,2)。
わが国における母子保健の水準は，戦後の乳幼児死亡 率の著明な改善にみられるでとく向上しているが，欧米 先進諸国と比較すると, 妊産婦死亡率および周産期死亡 率が高いなどの問題点が 今日な拢されている ${ }^{3,, 4), 5)}$ 。 このような現状のなかで, 総合的な母子保健対策を推進 する基本的条件として，中央児童福祉審議会 ${ }^{6}$ (は，母子 保健管理体系の確立, 一貫性と有機的関連をむった諸施 策の拡充強化, 市町村に㧧ける母子保健推進体制の育成 という三つの基本的方向を指摘している。

従来, 地域における母子保健活動は保健所を中心に推 進されてきたが, 昭和33年からは保健所から遠隔の地に 
ある農山漁村地区に母子健康センターの設置が開始され， 今日ではこれが乎子保健事業の拠点として期待されてお $り^{7)}$, 従って, 地域に扫ける母子の健康管理態勢の現状 から, 母子保健活動は保健所を中心に, 母子健康センタ 一を設置している地区ではそれを中心に行なわれている と考えられる。

本来, 健康管理は䂆防と治療を綜合したかたちで行な うべきであるが，それらの分離しているわが国の現行医 療制度の中にあっては, 綜合化は困難であり, 従って, 母子の健康管理に当たっても保健所を中心とする関係諸 機関の有機的な活動, 管理体系の確立が望まれている 5, , 8)

このような状況のなかで, 母子健康管理の一貫性を追 求するとき，妊娠加ら学令期までの母子の健康に関する 可能な限り多くの情報を一括して記録し，乙れを活用す る必要が指摘され, 今日すでにこれを目的とした管理票 の使用による管理の方式が試みられている ${ }^{91,10 。 し か し ~}$ 先に指摘したでとく，斿と治療の分離したわが国の医 療体制のなかにあっては, 医療機関からの情報が記入さ れ難く，また今日の社会情勢の急激な変化による都会で の転出入の問題も加わり, 管理票使用による管理にも一 定限度の制約が指摘 ${ }^{92}$ されている。一方，母子保健法第 16条による母子健康手帳は全国的な規模で組織的な配布 の体制が確立されて拈り, 前記諸条件を考慮するならば, 母子の健康管理上にはたす役割はきわめて大きいものが 期待される。

今日の母子健康手帳の前身をなすすのは，昭和17年の 䏕産婦手帳規程による妊産婦手帳である。妊産婦手帪の 初期の目的は, 娃婦をできる限り早く医学の領域に, 医 学の恩恵の屯とにもっていくという自然的效果を最大の 和らいとしていた ${ }^{11}$ 。徒って,ての手帳は妊産婦が診察, 治療, 保健指導または分浼の介助を受けたときは所定の 事項の記入を受けること, 妊産, 育児に関し必要な物資 の配給，その他妊産婦抽よび乳幼児保護のため必要な場 合に使用された。戦後, 昭和23年巟童福祉法の制定によ り, 妊産婦手帳規程はこれに吸収され, 名称も母子手帳 と改名された。この母子手帳の様式については, 数回の 改訂が試みられ, 昭和 41 年母子保健法の施行に伴い, 母: 子手帳はさらに母子健康手帳之改められた ${ }^{11), 12) 。 ~}$

今日,成人病に対する一般の関心のたかまりとともに, その管理指導の目的をむって，成人用の健康手帳の普及 がみられ，手帳使用による管理の成果あ報告されている 13),14)。一方, 学校保健の場に扎いても, 㫛童生徒の保健 管理, 保健指導を徹底させるための一つの手段として健
康手帳が利用されている(15),16),17)。このような状況をみ るとき，今日，生涯を通しての健康の記録圶残していく ことを可能にする条件は次第に整備されつつあると考え られる。特に母子健康手帳は，その歴史的な積み重ねが あり，しかあ全国的な規模で配布されている点，その活 用の実態に検討を加えることは，母子保健の向上のみな らず，国民の保健水準向上の点加らす有意義なものと考 える。

\section{II. 研究目的}

母子健康手帳は前述のごとく, 全国的な規模で配布さ れ, 歴史的にあ妊産婦手帳, 母子手帳之積み重ねがあり, その重要性および活用の必要性が指摘されている ${ }^{18), 19 ! 。 ~}$ しかし, 今日, 学校保健活動のなかで健康手帳が利用さ れまた成人病に対する関心のたかまりととあに，成人 用の健康手帳が普及しつつあるなかに扎いてさえ，母子 健康手帳に関する調査研究の実態は乳览検診あるいは 3 才児健診の際の記録の状況としてしか報告されているに すぎない20)。

今回, 著者は小学校入学まで使用できる母子健康手艮 の小学校 1 学年時における保存および記載状況を検討す るとともに，3才児健診時および小学校 1 学年時におけ る母親の子供についての発育・発達の評洒之記憶を残さ れた記録と比較検討し，記録の必要性亡母子健康手悵の 活用に際しての問題点を明らかにし，今後の母子の健康 管理に母子健康手帳を有効に利用する方策を見出さんと した。

\section{III. 研究対象扝よび方法}

研究刘象之しては，O県下 $\mathrm{S}$ 保健所管内の昭和41年度 大学の小学校 1 学年児童全員とし, 保管さ机ていた母. 手帳 (小学校 1 学年児童対象のあのは, 交付時加ら小学 校入学までほぼ全期間児童福祉法による母子手帳であっ た。)を回収し，その記載状況を検討するととるに，児童 の母親に対してアンケート調查を行なった。

母親の記憶と残された記録とを検討する目的では，さ 引にK県下T保健所管内で昭和 44 年度実施された 3 才坚 健診受診児の同伴者を対象とした。3才児健診時あらか じめ母子健康手帳（3才児対象のすのは出生時すでに母 子保健法の施行後である。)を回収し, 対象者に調査票を 配布して記入してもらった。乙の調查票の結果と母子健 康手帳および乳幼児検診に使用されたカルテの記載内容 との比較検討を行なった。 
Tab. 1 The number of the Booklets of mother and child health collected questionnairs sent and the answers returned

\begin{tabular}{|c|c|c|c|c|c|}
\hline Location & $\begin{array}{l}\text { No. of } \\
\text { questionnairs } \\
\text { (A) }\end{array}$ & $\begin{array}{c}\text { No. of } \\
\text { answers } \\
\text { (B) }\end{array}$ & & $\begin{array}{l}\text { No. } \\
\text { book }\end{array}$ & (C) \\
\hline S- $\quad$ city & 486 & 461 & $\begin{array}{l}\% \\
94.9\end{array}$ & 404 & $\begin{array}{l}\% \% \% \\
83.1\end{array}$ \\
\hline M- town & 164 & 150 & 91.5 & 119 & 72.6 \\
\hline A- town & 122 & 101 & 82.8 & 77 & 63.1 \\
\hline $\mathrm{T}-$ town & 163 & 147 & 90.2 & 122 & 74.8 \\
\hline C- town & 85 & 78 & 91.8 & 49 & 57.6 \\
\hline $\mathrm{K}-$ village & 45 & 43 & $\therefore 95.6$ & 35 & 77.8 \\
\hline $\mathrm{Y}-$ village & 39 & 38 & 97.4 & 33 & 84.6 \\
\hline Total & 1,104 & 1,018 & 92.2 & 839 & 76.0 \\
\hline
\end{tabular}

※ $\mathrm{B} / \mathrm{A} \times 100, \quad ※ ※ \mathrm{C} / \mathrm{A} \times 100$

Tab. 2 The rate of keeping the booklets

\begin{tabular}{|c|c|c|c|c|c|c|}
\hline Birth order & First ch & & Others & & Total & \\
\hline S- city & $\begin{array}{l}210 \% *: \\
218 \%\end{array}$ & $96.3^{9 / \%}$ & $\begin{array}{l}219 \% * \\
243 \%\end{array}$ & 90.1 & $\begin{array}{l}429 \% \% \\
\\
\end{array}$ & $93.1^{g / 4}$ \\
\hline M- town & 56 & 87.5 & 74 & 86.0 & 130 & 86.7 \\
\hline A- town & 38 & 88.4 & 41 & 70.7 & 101 & 78.2 \\
\hline $\mathrm{T}-$ town & 54 & 87.1 & 72 & 84.7 & 147 & 85.7 \\
\hline $\mathrm{C}-$ town & 25 & 86.2 & 32 & 65.3 & 57 & 73.1 \\
\hline $\mathrm{K}-$ village & 19 & 95.0 & 17 & 73.9 & 36 & 83.7 \\
\hline Y- village & 18 & 94.7 & 16 & 84.2 & 34 & 89.5 \\
\hline Total & 420 & 92.3 & 471 & 83.7 & 1,018 & 87.5 \\
\hline
\end{tabular}

The mark $※$ means the mumber of answers returned

The mark $※$ means the number of mothers who kept the booklet 
IV. 研究結果とその考察

1）母子手帳の保存状況

母子健康手帳は母子保健法によって妊娠の届出をした 者に対し都道府県知事（特別区のある区域にあっては， 特別区の区長) が交付し，小学校入学まで記載可能なむ のとして作製されている。

母子健康手帳の保存状況を小学校 1 学年時でみるとと は，それを健康管理汇活用するための基本的な条件と考 え, この時点での保存状況を調查した。市町村別の対象 者数执よびアンケート，母手帳回収状況は表 1 亿示す でとくであり，アンケートからみた母子手帳の保存状況 は表 2 亿示すような結果を得た。その結果，母子手帳の 保存は少なくとあ $76.0 \%$ 以上と良く，アンケートからみ る限りでは，87.5\%と保存率は極めて高かった。これは， 現状ではすでにその役割を失っているにあかかわらず， かつて配給手帳として利用されたという歴史的な積み重 ねが，いまなお母親の意識としては残っており，官給の 公用物に対する住民の態度として注目される。なお，某 地区に执いて行なった 1 才から 5 才までの未就学児対象 とした幼児検診における母子手帳保存率は $95.3 \%$ 之今回 の結果をさらに上まわっていた。
さらに，母子手帳の実際的な活用を保存状況との関連 で検討する目的で, 出生順位別に保存状況をみると, 表

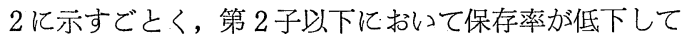
いるととが認められた。とのととは第 1 子における母子 手帳の実際的な利用の悪いととが第 2 子以下の保存を悪 くしたとも考えられ, 今後の母子健康手帳の利用に際し ての対策上注目すべき問題点が指摘され得た。母手悵 以外の記録の保存状況は表 3 亿示ずごとくである。半数 を越えるあのが何らかのかたちで記録を残しており，青 児日記はその作製目的, 使用方法により乳児の成育環境 を知る一つの方法とはなりえる ${ }^{21}$ が，発育の記録として は母于手帳の活用が充分なされるならば，高価な育児日 記やアルバムなどの必要性は少ないばかりか, 記録の分 散をあ考えあわせるならば，母子手帳の活用こそが今日 なお一層強調されるべきであるととが認められる。

3才児健診時における母子健康手帳の活用を知る目的 で，K県下T保健所管内で昭和 44 年実施された 3 才児健 診時に母子健康手帳の持参状況を調查した。表 4 亿示す ような対象者数および受診者数の 3 才児健款に際して, 3 才児に同伴した育児担当者を対象に調査票を配布した が, 同伴者の状況は表 5 のごとくであり, 以下母親同伴 のあのについて分析を行なった。その結果, 母子健康手

Tab. 3 Kinds of records for children's health history

\begin{tabular}{|c|c|c|c|c|c|c|c|c|c|c|c|}
\hline \multirow{3}{*}{$\begin{array}{l}\text { Location } \\
\text { S- city }\end{array}$} & \multirow{2}{*}{\multicolumn{2}{|c|}{$\begin{array}{l}\text { No. of answers } \\
\text { that mothers } \\
\text { kept records for } \\
\text { their children's } \\
\text { health history } \\
\text { (B) }\end{array}$}} & \multicolumn{4}{|c|}{ Kind of record } & \multirow{2}{*}{\multicolumn{2}{|c|}{$\begin{array}{l}\text { No. of answers } \\
\text { that mothers ke- } \\
\text { pt no records } \\
\text { for their child- } \\
\text { ren's health his- } \\
\text { tory }\end{array}$}} & \multirow{2}{*}{\multicolumn{2}{|c|}{ Not clear }} & \multirow{3}{*}{$\begin{array}{l}\text { Total } \\
\text { (A) } \\
461\end{array}$} \\
\hline & & & \multirow{2}{*}{$\begin{array}{c}\text { Album } \\
219\end{array}$} & \multirow{2}{*}{$\begin{array}{c}\begin{array}{c}\text { Nursing } \\
\text { diary }\end{array} \\
34\end{array}$} & \multirow{2}{*}{\begin{tabular}{|c}
$\begin{array}{c}\text { Mother's } \\
\text { diary }\end{array}$ \\
29
\end{tabular}} & \multirow{2}{*}{\begin{tabular}{|c|}
$\mid$ others \\
22
\end{tabular}} & & & & & \\
\hline & 254 & $\varlimsup_{55.1}$ & & & & & 160 & ※※ & 47 & 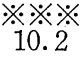 & \\
\hline M- town & 61 & 40.7 & 56 & 5 & 4 & 5 & 68 & 45.3 & 21 & 14.0 & 150 \\
\hline$A-$ town & 55 & 54.5 & 42 & 4 & 6 & 9 & 39 & 38.6 & 7 & 6.9 & 101 \\
\hline $\mathrm{T}-$ town & 74 & 50.3 & 72 & 10 & 8 & 9 & 59 & 40.1 & 14 & 9.5 & 147 \\
\hline C- town & 29 & 37.2 & 27 & 2 & 3 & 1 & 31 & 39.7 & 18 & 23.1 & 78 \\
\hline $\mathrm{K}-$ village & 29 & 67.4 & 27 & 3 & 7 & 1 & 11 & 25.6 & 3 & 7.0 & 43 \\
\hline Y- village & 21 & 55.3 & 20 & 2 & 1 & 1 & 17 & 44.7 & 0 & 0 & 38 \\
\hline Total & 528 & 51.4 & 463 & 60 & 58 & 41 & 385 & 37.8 & 110 & 10.8 & 1,018 \\
\hline
\end{tabular}

$※ \mathrm{~B} /{ }_{\mathrm{A}} \times 100, ※ \circledast_{\mathrm{C} / \mathrm{A}} \times 100, ※ \circledast_{\mathrm{D} / \mathrm{A}} \times 100$ 
悵を持参したものは表 6 亿示すでとく $88.0 \%$ となって 抢り, 町村別にみると保存率とは異なって, かなり低率

Tab. 4 The numbe of 3 -year-old children ${ }^{+}$who received heath examination

\begin{tabular}{l|r|r|r|r|r}
\hline Location & $\begin{array}{l}\text { No. of } \\
\text { children } \\
\text { (A) }\end{array}$ & $\begin{array}{l}\text { No. of examinee } \\
\text { to the health } \\
\text { exam. }\end{array}$ & $\begin{array}{l}\text { No. of children } \\
\text { examined for } \\
\text { this study }\end{array}$ \\
\hline y- town & 167 & 122 & 73.1 & 120 & $\begin{array}{r}\text { (C) } \\
98.4\end{array}$ \\
\hline n- town & 84 & 61 & 72.6 & 58 & 95.1 \\
\hline k- town & 39 & 32 & 82.1 & 31 & 96.9 \\
\hline $\begin{array}{l}\text { y- villa- } \\
\text { ge }\end{array}$ & 25 & 23 & 92.0 & 23 & 100.0 \\
\hline c- town & 42 & 38 & 90.5 & 38 & 100.0 \\
\hline $\begin{array}{l}\text { m- villa- } \\
\text { ge }\end{array}$ & 51 & 35 & 68.3 & 35 & 100.0 \\
\hline Total & 408 & 311 & 76.2 & 305 & 98.1 \\
\hline
\end{tabular}

※ $/ \mathrm{A} \times 100, \ldots ※ \mathrm{C} / \mathrm{B} \times 100$

+ Every local government schould provide health examination for 3-year-old children by the Law

Tab. 6 The rate of mothers who brought the booklets at the health examination and the number of their children's clinical charts kept at the Health Center

\begin{tabular}{|c|c|c|c|c|c|c|c|}
\hline Location & $\begin{array}{l}\text { Mothers w } \\
\text { brought th } \\
\text { booklets }\end{array}$ & & $\begin{array}{l}\text { Mothers } \\
\text { without } t \\
\text { booklet }\end{array}$ & & $\begin{array}{l}\text { Total } \\
\text { (A) }\end{array}$ & clinical & $\begin{array}{l}\text { o. of } \\
\text { charts } \\
\text { (D) }\end{array}$ \\
\hline $\mathrm{y}^{-}$town & 101 & 94.4 & 6 & $※ ※$ & 107 & 71 & $\begin{array}{r}※ ※ \% \\
66.4\end{array}$ \\
\hline$n-$ town & $\begin{array}{l}4^{+} \\
(16) \\
\end{array}$ & 93.9 & 3 & 6.1 & 49 & 36 & 73.5 \\
\hline$k-$ town & 11 & 42.3 & 15 & 57.7 & 26 & 19 & 73.1 \\
\hline$y-\quad$ village & 16 & 88.9 & 2 & 11.1 & 18 & 7 & 38.9 \\
\hline$c-$ town & 30 & 90.9 & 3 & 9.1 & 33 & 29 & 87.9 \\
\hline$m-$ vllage & 30 & 90.9 & 3 & 9.1 & 33 & 32 & 97.0 \\
\hline Total & 234 & 88.0 & 32 & 12.0 & 266 & 194 & 72.9 \\
\hline
\end{tabular}

$※ \mathrm{~B} /{ }_{\mathrm{A}} \times 100, ※ \%^{\mathrm{C}} / \mathrm{A} \times 100, ※ ※ \%^{\mathrm{D}} / \mathrm{A} \times 100$

the mark+means the number of mothers with the booklets but not examined
を示すととろが認められた。これは，町村における担当 者の母親への通知および指導が不充分のため, 健診時, 母子健康手帳を持参するととが習慣づけられていないた めと推測される。母子手帳の保存が必ずしもその活用を 意味しておらず，逆に，先に指摘したごとく活用の実体

Tab.5 Accompanying persons to health examination of 3 -year-old children

\begin{tabular}{l|r|r|r|r|r}
\hline Location & Mother & $\begin{array}{c}\text { Grand- } \\
\text { mother }\end{array}$ & Father & Others & Total \\
\hline y-town & 107 & 7 & 3 & 3 & 120 \\
\hline n-town & 49 & 9 & - & - & 58 \\
\hline \begin{tabular}{l} 
k-town \\
\hline $\begin{array}{l}\text { g- villa- } \\
\text { ge }\end{array}$
\end{tabular} & 18 & 4 & - & 1 & 23 \\
\hline \begin{tabular}{l} 
c-town \\
\hline $\begin{array}{l}\text { g-villa- } \\
\text { ge }\end{array}$
\end{tabular} & 33 & 5 & - & - & 38 \\
\hline \begin{tabular}{c} 
Total \\
\hline
\end{tabular} & 266 & 29 & 6 & 4 & 305 \\
\hline
\end{tabular}


Tab. 7 Mother's interests on nursing

\begin{tabular}{|c|c|c|c|c|c|c|c|c|c|c|c|c|c|c|}
\hline \multirow{3}{*}{$\begin{array}{l}\text { Location } \\
\text { S- city }\end{array}$} & \multirow{2}{*}{\multicolumn{2}{|c|}{$\begin{array}{l}\text { No. of mo- } \\
\text { thers hav- } \\
\text { ing the in } \\
\text { terests } \\
\text { (B) }\end{array}$}} & \multicolumn{7}{|c|}{ Kind of interests } & \multirow{2}{*}{\multicolumn{2}{|c|}{$\begin{array}{l}\text { No. } \\
\text { interests } \\
\text { (C) }\end{array}$}} & \multirow{3}{*}{$\begin{array}{r}\text { D.N. } \\
11\end{array}$} & \multirow{3}{*}{$\begin{array}{r}\text { N.A. } \\
19\end{array}$} & \multirow{3}{*}{\begin{tabular}{|r} 
Tota \\
(A) \\
461
\end{tabular}} \\
\hline & & & \multirow{2}{*}{\begin{tabular}{|r|}
\begin{tabular}{|} 
Body. \\
grow- \\
th
\end{tabular} \\
\\
78
\end{tabular}} & \multirow{2}{*}{\begin{tabular}{|c|} 
Intelli- \\
gence
\end{tabular}} & \multirow{2}{*}{\begin{tabular}{|r|}
$\begin{array}{l}\text { Emo- } \\
\text { tion }\end{array}$ \\
48
\end{tabular}} & \multirow{2}{*}{\begin{tabular}{|r|}
$\begin{array}{c}\text { Sick- } \\
\text { ness }\end{array}$ \\
97
\end{tabular}} & \multirow{2}{*}{\begin{tabular}{|l|}
$\begin{array}{l}\text { Nutri } \\
\text { tion }\end{array}$ \\
109
\end{tabular}} & \multirow{2}{*}{\begin{tabular}{|l|}
$\begin{array}{l}\text { Train } \\
\text { ing }\end{array}$ \\
144
\end{tabular}} & \multirow{2}{*}{\begin{tabular}{|c|} 
\\
8
\end{tabular}} & & & & & \\
\hline & 310 & $\% 67.2$ & & & & & & & & 121 & {$\left[\begin{array}{cc}\% \\
26.2\end{array}\right.$} & & & \\
\hline M-town & 99 & 66.0 & 18 & 21 & 16 & 40 & 38 & 46 & 6 & 29 & 19.3 & 8 & 14 & 150 \\
\hline A-town & 56 & 55.4 & 18 & 15 & 13 & 23 & 23 & 22 & 1 & 34 & 33.7 & 2 & 9 & 101 \\
\hline T-town & 98 & 66.7 & 28 & 24 & 12 & 35 & 36 & 43 & 8 & 34 & 23.1 & 8 & 7 & 147 \\
\hline C-town & 53 & 67.9 & 19 & 14 & 6 & 18 & 19 & 21 & 7 & 18 & 23.1 & 1 & 6 & 78 \\
\hline $\mathrm{K}$-village & 25 & 58.1 & 8 & 5 & 3 & 9 & 6 & 5 & - & 12 & 27.9 & 3 & 3 & 43 \\
\hline Y-village & 26 & 68.4 & 7 & 8 & 5 & 6 & 6 & 15 & - & 9 & 23.7 & 2 & 1 & 38 \\
\hline Total & 667 & 65.5 & 185 & 155 & 103 & 228 & 237 & 296 & 30 & 257 & 25.5 & 35 & 59 & 1,018 \\
\hline
\end{tabular}

$\mathrm{B}_{\mathrm{B}} \times 100, \ldots \mathrm{C}_{\mathrm{C}} / \mathrm{A} \times 100$

が保存率に影響を与える点, 今後の対策上に重要な指針 を与えるあのといえよう。なお，乙れら持参した母子健 康手帳と乳幼児検診カルテとの照合を目的としてカルテ の保健所における保存率をみると $72.9 \%$ と決して高くな かった。以上の結果から母子健康手悵の有効な活用がそ の保存に影響を与えること, 有效な活用のた始には, 少 なくと屯健診時に母子健康手悵の持参が要請されなけれ ばならず，ての点でも現状の地域保健活動において決し て充分に配慮されているとはいえず，今後の具体的な指 導の方向性を明らかにし得た。

このような母子手帳の保存状況のなかで, 母親の子供 の発育についての関心度を知るととは, 母親の母子健康 手帳の活用に対する動機づけを理解する点で意義がある と考え, 子供の発育についての母親の不安を養育者であ る母親に尋ねた。その結果, 表 7 に示すでとく母親の子 供の発育についての関心は病気, 栄養, しつけについて, 身体, 知能, 情緒に対するより高くなっていた。てのと とは, 病気, 栄養, しつけの面で母子健康手帳の活用に ついても, さらに慎重な配慮が必要であることを指示し ていると考えられる。

2）母:手帳の記載状沉

目手手帳の利用状況を検討する目的で, 小学校 1 学年
時に抢ける母子手帳の記載状況を調査した結果は図 1 の ごとくである。娃産婦の項についてみると，妊婦の検診 および打産の記事は74.1\%，98.0\%記載が良いが，妊 婦の記事打よび産後の母:健康状態の記事は記載が悪く なっている。子供の項についてみると, 新生児の記事 ( 出生時）は96.7\% と良く, 誕生前後, 満 3 才前後の幼児 の健康状態の記事は，それぞれ79.6\%，52.4\% と記載率 が低下し, それ以降, 幼児における健康管理の行政上の

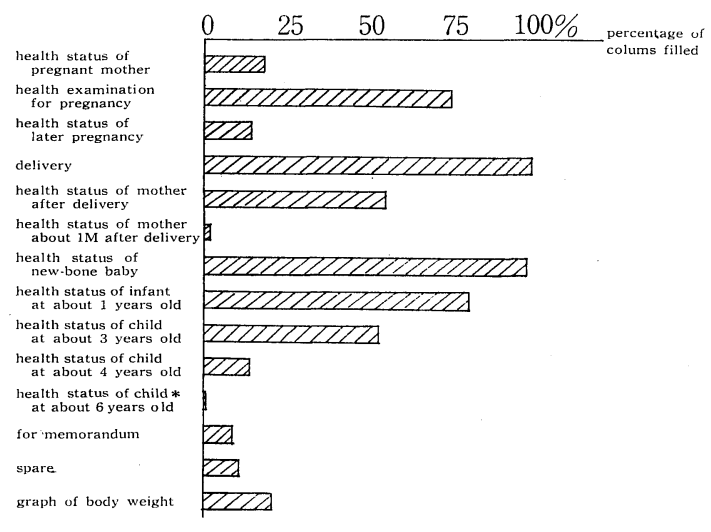

Fig. 1 What kinds of column are filled?, 
手薄さとも関連して, ほとんど記載されていなかった。 小学校入学前の健康晾断についても母子手帳の利用は認 められなかった。このことは，林の指摘8 するごとく， 幼稚園之保育所のように同じ幼児を扱いながら，その所 管を異にするための不都合，就学前の健康診断が保健所 の幼児管理とは無関係に行なわれているとと，母健康 手帳がありながら学校の健康簿につながっていないな よ゙，関係機関の有機的な連絡の欠如が団尒健康手帳の活 用に大きな影響をもっているととを示していると考えら れる。

さらに，母親の自主的な記入欄であるおぼえ青，予備 欄の記載も悪く，子供の病気，栄養，しつけに対する 母親の関心が高いにかかわらず，それらを有効な記録と して残していない現状を考え合わせるとき，母子健康手 帳の記載に対する母親の認識, 態度において, 今後検討 されるべき問題点を示していることが認められ，今後の 母子健康手帳活用上の対策における具体的な指針を得
Fig. 2 Receiving time of the booklets

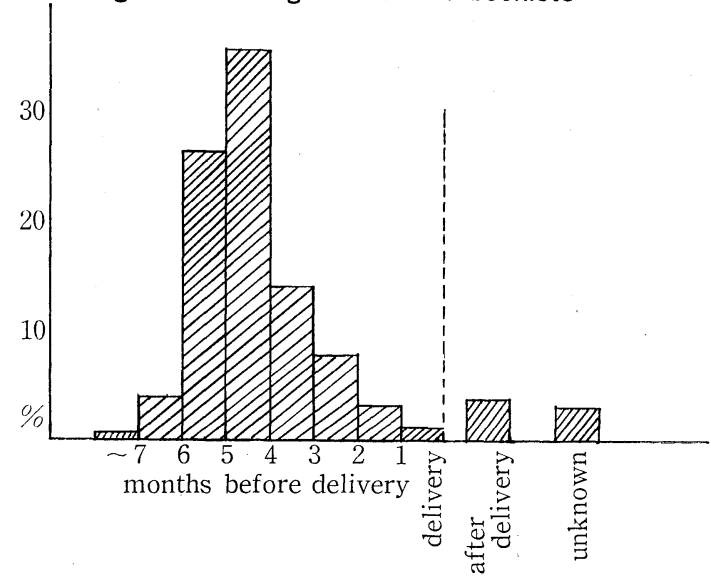

た。発育值を示すグラフの活用は $20.6 \%$ と悪く, しか あ, 満 1 才を越えて記入しているあのはほとんどなく， 発育状態を知る目的を達しているとはいえない現状を認

S-cit

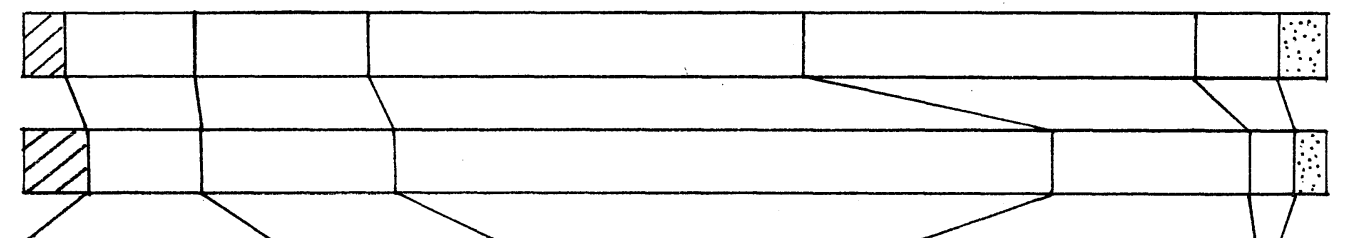

A-town

T-town

C-town

$\mathrm{K}$-village

$\mathrm{Y}$-village

Total

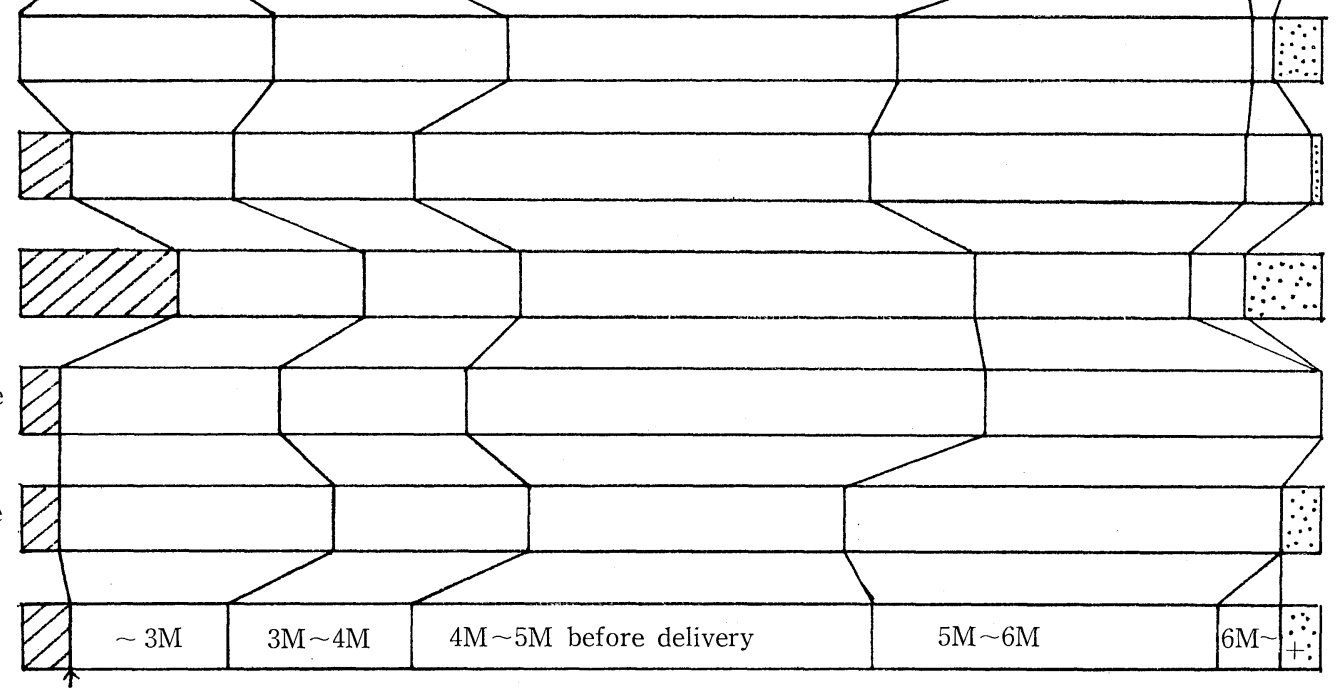

delivery

after delivery

unknown

Fig. 3 Receiving time of the booklets classified by location 
めえた。昭和 43 年に実施された母子保健実態調査 ${ }^{22}$ によ ると，産婦について産婦自身が記入すべき事項の活用状 況は，優预よび良の産婦が52\%となっており，残る48\% に扔いては活用されてないとと，また，母子健康手帳の 活用状況は, 市部が郡部より良いなどの事実が報告され ている。

発育記録の始まりであり，娃婦の健康管理における対 象把握の時期である母子手帳交付時期は図 2 亿示すごと くである。市町村別の交付時期は図 3 のごとく, 市町村 によって若干の特異性が認められた。出生後交付を受け たすのあ $3.8 \%$ 認められた。杉原 ${ }^{23}$ は分婏後交付を受け た家庭は妊産婦自身の身体や子供の問題だけでなく, 健 康に関するすべての知識がきわめて低く, しかも, 経佩 的，社会的にあ恵まれない環境にあることを指摘してい る。乙の事実と関連して，母子手帳交付時期と妊婦検部 記入回数をみたのが図 4 である。交付時期の早い程，記 入回数が多くなって抢り, 交付時期之管理内容との関連 がこの面からむ指摘し得た。

3 才児の母親について, その子供の妊娠中の検診受診 状況とその結果の記憶状況扔よび母子健康手帳への記入

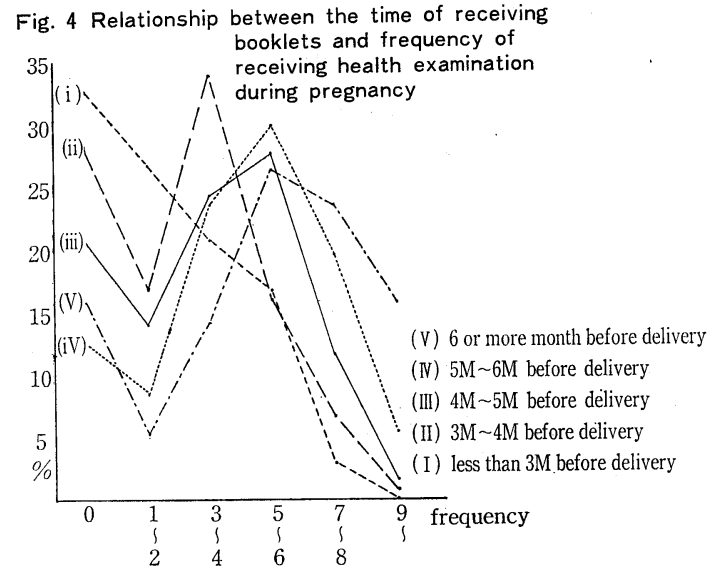

状況を検討すると，妊娠中の受䛦状況は表 8 に示すでと くであり, 受䛦結果の記憶状況については表 9 亿示すで とく, 検診内容によって記載率, 記憶率抢よび後に検討 する記載内容と記憶との一致率に差が認められたが，こ れは検診内容, 検診に対する母親の態度, 認識および検 診受䛦回数との関連が考えられる。

Tab. 8 Mother's memory of receiving health examination during her pregnancy

\begin{tabular}{|c|c|c|c|c|c|c|c|}
\hline \multirow{2}{*}{$\begin{array}{l}\text { Kind of } \\
\text { examination }\end{array}$} & \multirow{2}{*}{$\begin{array}{l}\text { No. of } \\
\text { answers } \\
\text { (A) }\end{array}$} & \multicolumn{4}{|c|}{$\begin{array}{l}\text { No. of mothers } \\
\text { with memory }\end{array}$} & \multirow{2}{*}{\multicolumn{2}{|c|}{$\begin{array}{l}\text { No. of mot hers } \\
\text { without } \\
\text { memory } \\
\text { (D) }\end{array}$}} \\
\hline & & \multicolumn{2}{|c|}{$\begin{array}{l}\quad(\mathrm{B}) \\
\text { receiving } \mathrm{H} \text {. } \\
\text { E. }\end{array}$} & \multicolumn{2}{|c|}{$\begin{array}{ll} & (\mathrm{C}) \\
\text { not receiv- } & \text { rece } \\
\text { ing } \mathrm{H} . \mathrm{E} .\end{array}$} & & \\
\hline Blood pressure & 266 & 235 & $\begin{array}{c}* \% \\
88.3\end{array}$ & 21 & $\begin{array}{c}* \% \text { 落 } \\
7.9\end{array}$ & 10 & $\begin{array}{c}* \% \% \\
3.8\end{array}$ \\
\hline Urine test & 266 & 245 & 92.1 & 10 & 3.8 & 11 & 4.1 \\
\hline Exam. for anemia & 266 & 111 & 41.7 & 117 & 44.0 & 38 & 14.3 \\
\hline
\end{tabular}

$※ \mathrm{~B} /{ }_{\mathrm{A}} \times 100, ※{ }^{\mathrm{C}} /{ }_{\mathrm{A}} \times 100, ※ \circledast_{\mathrm{D} / \mathrm{A}} \times 100$

Tab. 9 Mother's memory of the results of health examination during her pregnancy

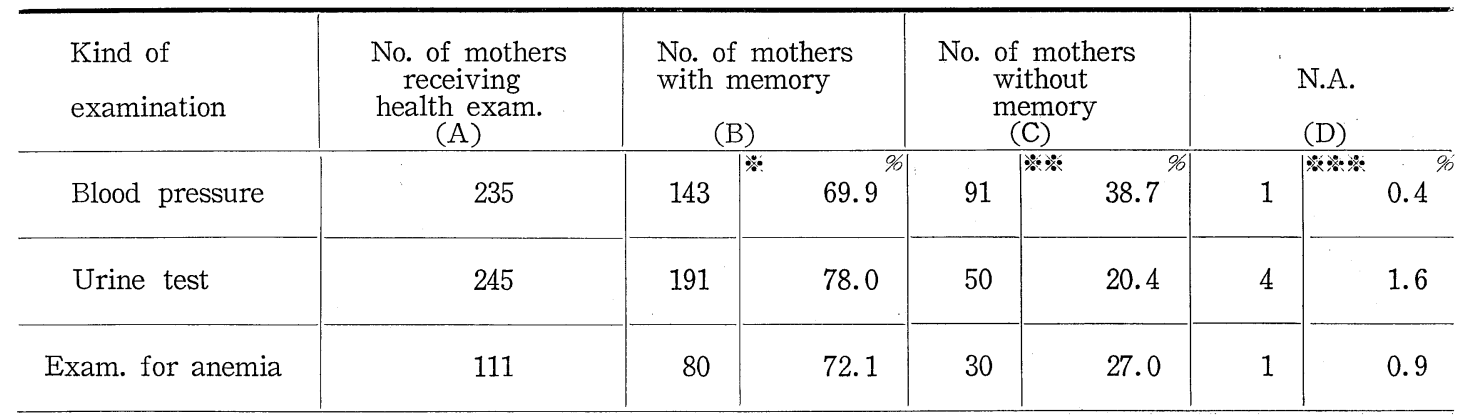

$※ \mathrm{~B} / \mathrm{A} \times 100, \circledast_{\mathrm{C} / \mathrm{A}}^{\mathrm{C}} \times 100, ※ \circledast \mathrm{D}_{\mathrm{A}} \times 100$ 
Tab.10 Relationship between mother's memory and record of receiving health examination during her pregnancy

\begin{tabular}{|c|c|c|c|c|}
\hline \multirow{4}{*}{ 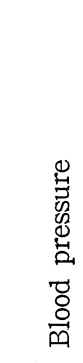 } & $\begin{array}{l}\text { No. of Memory } \\
\text { booklets }\end{array}$ & $\begin{array}{l}\text { receiving } \\
\text { health exam. }\end{array}$ & $\begin{array}{l}\text { not receiving } \\
\text { health exam. }\end{array}$ & forgotten \\
\hline & Total & 193 & 17 & 8 \\
\hline & $\begin{array}{l}\text { recorded the result of } \\
\text { the exam. }\end{array}$ & 170 & 5 & 3 \\
\hline & $\begin{array}{l}\text { without any record of } \\
\text { the result of the exam. }\end{array}$ & 23 & 12 & 5 \\
\hline \multirow{3}{*}{ 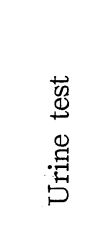 } & Total & 203 & 9 & 6 \\
\hline & $\begin{array}{c}\text { recorded } \\
\text { the result of the exam. }\end{array}$ & 168 & 8 & 2 \\
\hline & $\begin{array}{l}\text { without any record of } \\
\text { the result of the exam. }\end{array}$ & 35 & 1 & 4 \\
\hline \multirow{3}{*}{ 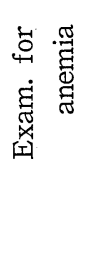 } & Total & 90 & 100 & 28 \\
\hline & $\begin{array}{l}\text { recorded the result } \\
\text { of the exam. }\end{array}$ & 9 & 3 & 2 \\
\hline & $\begin{array}{l}\text { without any record of } \\
\text { the result of the exam. }\end{array}$ & 81 & 97 & 26 \\
\hline
\end{tabular}

母子健康手帳への記入状況は表10に示すでとく, 貧血 検査については, 受けたと答え, しかもその結果が母子 健康手帳に記入されているあのは $10.0 \%$ ときわめて低い 值を示しており, 賓血検査結果の記入が, 血圧, 検尿の それよりきわめて悪いのが注目された。一方, 血圧, 検 尿については, 受けたと答えながら母子健康手帳に記入 のないあのがそれぞれ $11.4 \%, 17.2 \%$ 認められ，乙れは， 受けないと答えながら実際は母子健康手帳に結果が記入 されている明らかな記憶ちがいが認められたてとから, 母親の記憶ちがいによるか，実際は検診を受けながら母 子健康手帳への記入がされなかったためと推測される。

母子健康手帳の交付は妊娠したととを, 多くは医師, 助産婦に診断され，その上で妊娠の届出を提出して受け るが, その際, 血圧, 検尿などの検查を受けたにあかか わらず，母子健康手帳交付後にその結果が記載されてい ない現状が指摘され得た。妊婦の記事，即ち妊婦の既往 歴についても母子健康手帳の活用が，今日なお不充分で あり今後の対策が期待される。

次に，予防接種欄の記載状況は図 5 亿示すごとく，種
痘の第 1 期, 百日咳, ジフテリアの第 1 期は接種率を考 慮すると記載状況はきわめて良く，各市町村において舟 子手帳が䂆方接種の際の入場券的な役割をはたしている 現状を認め得た。な报，百日咳，ジフテリアについては， すでに混合ワクチンが使用されており，記載欄が二つに

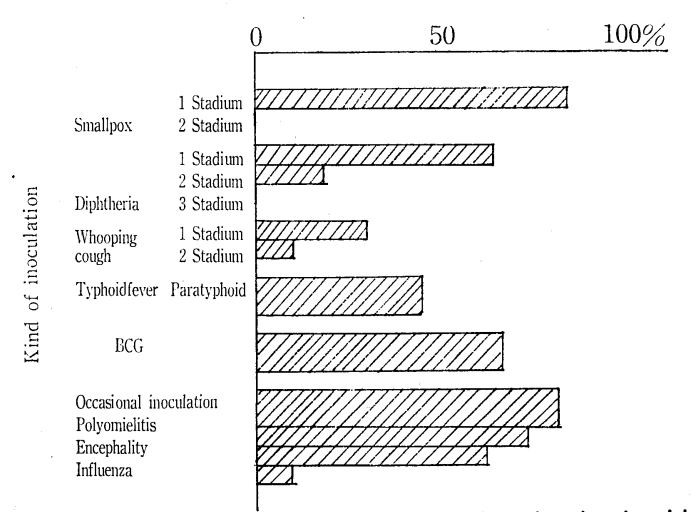

Fig. 5 Records of inoculation in the booklet percentage of children with records in the booklet 
分かれているため，図のような状況を示しているといえ よう。種痘の第 2 期掞よびジフテリアの第 3 期は小学校 入学前に行なわれるが，母子手帳の入学前の健康状態記
入欄と同様の理由で記載がなされていなかった。

䂆防接種の有無に関する記憶とその母子健康手帳への

記入状況を 3 才児健晾時にみると表 11 , 表 12 示すごと

Tab.11 Mother's memory of her child's innoculation including tuberculin test

\begin{tabular}{|c|c|c|c|c|c|c|c|}
\hline \multirow{3}{*}{$\begin{array}{l}\text { Kind of } \\
\text { innoculation } \\
\text { Smallpox }\end{array}$} & \multirow{3}{*}{$\begin{array}{l}\text { Total } \\
\text { (A) } \\
266\end{array}$} & \multicolumn{4}{|c|}{ with memory } & \multirow{2}{*}{\multicolumn{2}{|c|}{$\begin{array}{l}\text { forgotten } \\
\text { (D) }\end{array}$}} \\
\hline & & \multicolumn{2}{|c|}{$\begin{array}{l}\text { receiving } \\
\text { innoculation (B) }\end{array}$} & \multicolumn{2}{|c|}{$\begin{array}{l}\text { not receiving } \\
\text { innoculation (C) }\end{array}$} & & \\
\hline & & 244 & $\% 91.7^{\%}$ & 5 & $1.9^{\% / 7}$ & 17 & 6.4 \\
\hline $\begin{array}{l}\text { Whooping cough, Diphthe- } \\
\text { ria }\end{array}$ & 266 & 250 & 94.0 & 6 & 2.3 & 10 & 3.8 \\
\hline Poliomyelitis & 266 & 254 & 95.5 & 7 & 2.6 & 5 & 1.9 \\
\hline Measles & 266 & 79 & 29.7 & 161 & 60.5 & 26 & 9.8 \\
\hline Tuberculin test & 266 & 231 & 86.8 & 13 & 4.9 & 22 & 8.3 \\
\hline B.C.G. & 266 & 229 & 86.1 & 21 & 7.9 & 16 & 6.0 \\
\hline
\end{tabular}

$※ \mathrm{~B} / \mathrm{A} \times 100, ※ \circledast^{\mathrm{C}} / \mathrm{A} \times 100, ※ \circledast^{\mathrm{D} / \mathrm{A}} \times 100$

Tab.12 Relationship between memory and records of receiving innoculation

\begin{tabular}{|c|c|c|c|c|c|c|c|c|c|}
\hline & of & $\begin{array}{l}\text { receiving } \\
\text { innocula- } \\
\text { tion }\end{array}$ & $\begin{array}{l}\text { not receiv- } \\
\text { ing in- } \\
\text { noculation }\end{array}$ & $\begin{array}{l}\text { forgot- } \\
\text { ten }\end{array}$ & & of & $\begin{array}{l}\text { receiving } \\
\text { innocula- } \\
\text { tion }\end{array}$ & $\begin{array}{l}\text { not receiv- } \\
\text { ing in- } \\
\text { noculation }\end{array}$ & $\begin{array}{l}\text { forgot- } \\
\text { ten }\end{array}$ \\
\hline & Total & 204 & 4 & 10 & & Total & 63 & 132 & 23 \\
\hline 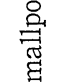 & $\begin{array}{l}\text { recorded } \\
\text { in the booklet }\end{array}$ & 159 & 1 & 6 & 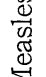 & $\begin{array}{c}\text { recorded } \\
\text { in the booklet }\end{array}$ & 7 & 0 & 0 \\
\hline & $\begin{array}{l}\text { not recorded } \\
\text { in the booklet }\end{array}$ & 45 & 3 & 4 & & $\begin{array}{l}\text { not recorded } \\
\text { in the booklet }\end{array}$ & 56 & 132 & 23 \\
\hline & & & & & & & & & \\
\hline 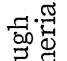 & Total & 207 & 2 & 9 & $\vec{y}$ & Total & 191 & 10 & 17 \\
\hline 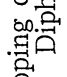 & $\begin{array}{c}\text { recorded } \\
\text { in the booklet }\end{array}$ & 165 & 1 & 7 & 总 & $\begin{array}{c}\text { recorded } \\
\text { in the booklet }\end{array}$ & 71 & 1 & 3 \\
\hline & $\begin{array}{l}\text { not recorded } \\
\text { in the booklet }\end{array}$ & 42 & 1 & 2 & $\stackrel{F}{\xi}$ & $\begin{array}{l}\text { not recorded } \\
\text { in the booklet }\end{array}$ & 120 & 9 & 14 \\
\hline & & & & & & & & & \\
\hline$\cong$ & Total & 209 & 6 & 3 & & Total & 191 & 15 & 12 \\
\hline 兽 & $\begin{array}{l}\text { recorded } \\
\text { in the booklet }\end{array}$ & 139 & 4 & 2 & $\begin{array}{l}\dot{0} \\
\dot{0} \\
\dot{m}\end{array}$ & $\begin{array}{c}\text { recorded } \\
\text { in the booklet }\end{array}$ & 43 & 1 & 2 \\
\hline مि & $\begin{array}{l}\text { not recorded } \\
\text { in the booklet }\end{array}$ & 70 & 2 & 1 & & $\begin{array}{l}\text { not recorded } \\
\text { in the booklet }\end{array}$ & 148 & 14 & 10 \\
\hline
\end{tabular}


く, 麻疹は予防接種法に規定がなく, 個人の自主的な判 断で䛦療所, 病院などの医療機関において個別に受ける あのなので, 種痘, 百日咳, ジフテリア，小児麻疩など の予防接種法に基づく集団接種とはことなった状況を認 め得た。即ち，麻疹については受けたと答えながら母子 健康手帳への記入が少なく，医療機関への母子健康手帳 持参ととあに，そてでの記入の悪いととが 推測され得 る。ツ反および B.C.G. の記入なしが多いのは, 実施場所 が市町村，保健所あるいは医療機関実施の場合でことな り，これら医療機関への母親の母子健康手帳持参に対す る態度および実施者側の母子健康手帳への記入に対する 態度の差が 母子健康手帳の活用に重要な役割を有して いることが認められた。予防接種についても受けないと
答えながら実際は母子健康手帳へ記入のある, 明らかに 記憶ちがいのあのが若干認められた。

子供の発達についての母親の記憶をみると表13に示す 結果を得た。独り歩き，お坐りは著明な変化として把握 しやすく，記憶が良くなっているが，精神発達上のマイ ルストンである，笑う，首がすわる，一語をいうについ ては記憶が悪く，これら記憶の悪い項目こそ正確に記録 を残しておくべきであり, 今後母子健康手帳の改訂に際 しては, 記載すべき項目についての充分な考慮がなされ る必要があるととを指摘し得る。乳幼览検診時使用の力 ルテ記入之の関係をみると表14に示すごとく，カルテへ の記入むまた充分でなく, 検診者の発育, 発達について の関心の薄いととが認められた。とのととは検診回数と

Tab.13 Mother's memory of her child's development

\begin{tabular}{|c|c|c|c|c|c|c|c|}
\hline No."of mothers & & $\begin{array}{l}\text { th } \\
\text { mory } \\
\text { (B) }\end{array}$ & & $\begin{array}{l}\text { hout } \\
\text { emory } \\
\text { C) }\end{array}$ & & & $\begin{array}{l}\text { Total } \\
\text { (A) }\end{array}$ \\
\hline Holds head & 170 & ※ $63.9^{\%}$ & 96 & $※ ※ \%$ & 0 & $\%$ & 266 \\
\hline Walks alone & 246 & 92.5 & 20 & 7.5 & 0 & & 266 \\
\hline $\begin{array}{l}\text { Stretch arms } \\
\text { and Grasps }\end{array}$ & 89 & 33.5 & 177 & 66.5 & 0 & & 266 \\
\hline $\begin{array}{l}\text { Expresses Recognition } \\
\text { of persons }\end{array}$ & 108 & 40.6 & 155 & 58.3 & 3 & 1.1 & 266 \\
\hline Sits alone & 186 & 69.9 & 80 & 30.1 & 0 & & 266 \\
\hline Smiles & 123 & 46.2 & 143 & 53.8 & 0 & & 266 \\
\hline Says one word & 108 & 40.6 & 157 & 59.0 & 1 & 0.4 & 266 \\
\hline
\end{tabular}

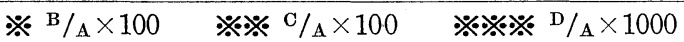

Tab.14 Relationship between mother's memory and records of her child's development in the chart

\begin{tabular}{|c|c|c|c|}
\hline \multicolumn{2}{|c|}{ No. of clinical charts } & $\begin{array}{c}\text { with } \\
\text { memory }\end{array}$ & $\begin{array}{l}\text { without } \\
\text { memory }\end{array}$ \\
\hline \multirow{3}{*}{ 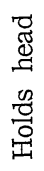 } & Total & 127 & 67 \\
\hline & recorded in the chart & 59 & 32 \\
\hline & not recorded in the chart & 68 & 35 \\
\hline & & & \\
\hline \multirow{3}{*}{ 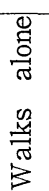 } & Total & 181 & 13 \\
\hline & recorded in the chart & 59 & 2 \\
\hline & not recorded in the chart & 122 & 11 \\
\hline
\end{tabular}




\begin{tabular}{|c|c|c|c|}
\hline \multicolumn{2}{|c|}{ No. of clinical charts } & $\begin{array}{l}\text { with } \\
\text { memory }\end{array}$ & $\begin{array}{l}\text { without } \\
\text { memory }\end{array}$ \\
\hline \multirow{3}{*}{ 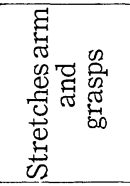 } & Total & 66 & 66 \\
\hline & recorded in the chart & 0 & 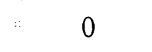 \\
\hline & not recorded in the chart & 66 & 128 \\
\hline \multirow{4}{*}{ 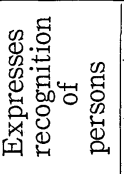 } & Totor & & \\
\hline & Total & 80 & $112(2)$ \\
\hline & recorded in the chart & 4 & 3 \\
\hline & not recorded in the chart & 76 & 109 \\
\hline \multirow{3}{*}{ 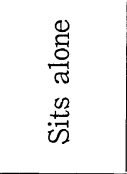 } & Total & 136 & 58 \\
\hline & recorded in the chart & 38 & 23 \\
\hline & not recorded in the chart & 98 & 35 \\
\hline & & & \\
\hline \multirow{3}{*}{ 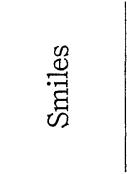 } & Total & 89 & 105 \\
\hline & recorded in the chart & 28 & 24 \\
\hline & not recorded in the chart & 61 & 81 \\
\hline 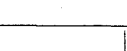 & & & \\
\hline \multirow{3}{*}{ 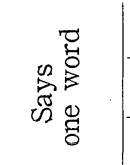 } & Total & 76 & $117(1)$ \\
\hline & recorded in the chart & 2 & 5 \\
\hline & not recorded in the chart & 74 & 122 \\
\hline
\end{tabular}

( ) : no answer

の関係むむり, 発達の各段階についてのチェックが現状 の検診回数では充分になされ得ないてととあ関連して母 子健康手帳の活用における, 検診および管理者としての 保健活動従事者の責任が明らかにされ得た。

子供の発達についての母親の記憶とカルテ記載の時期 との関係は表 15 に示すごとく,一致率は50\%前後と低く， 母親の判定之医師あるいは保健婦など専門家の判定との 相異を認めた。乙れが解釈の相異によるあのか, あるい は，母親自身の記憶の不正確さによるあのかはただち に結論を下し得ないが，いづれにしてあ母子健康手帳 の活用によって, ある程度解決され得る問題であろ う。

子供の出生時の体重について, 母親の記憶の正確さを 知る目的で母親の記憶と母子健康手帳に記載されている 体重とを照合した結果は表16亿示すでとく，記憶ありと 答えたあのが84.6\%で，そのなかで母子健康手帳と照合 出来たむのについて，その一致率をみると， $30.1 \%$ あ
のが不一致であり，母親の乳幼肾の成長にからむ記憶の 不正確さを指摘し得た。

3）母親の発育評価

母親の子供の発育に対する評価を知るととは保健指導 を行なう上で重要であり, 乳児期, 幼児期(満三才前後) および小学校 1 学年時における子供の身長, 体重, 胸团 についての母親の判定を, 厚生省乳幼児発育值 ${ }^{24)}$ 抢よび 学校保健統計調查報告書 ${ }^{25}$ ) (昭和40年度) と比較し, そ の適中率をみた結果, 小学校 1 学年時の身長が 最高で $69.7 \%$, 幼児期の胸囲が最低で44.8\%であり, 発育值小 のあのについて適中率が悪いととが認められた。

実測值と母親の判定との相異を年令経過をおった結果 は図 9 に示すでとくである。身長については, 幼児期, 小学校 1 学年時になるにつれ相異が改善されており, 母 親の注意が乳児期の体重から歩き始める幼児期には身長 に移行している一方, 体重については各時期を通して変 化の少ないてとが認められた。体格について, 身長, 体 
Tab.15 Relationship between mother's memory and records of her child's development in the chart

\begin{tabular}{|c|c|c|c|c|c|}
\hline & \multirow{2}{*}{$\begin{array}{l}\text { No. of } \\
\text { records } \\
\text { (A) }\end{array}$} & \multirow{2}{*}{\multicolumn{2}{|c|}{$\begin{array}{l}\text { No. of mothers } \\
\text { memory in } \\
\text { accordance } \\
\text { with the records } \\
\text { (B) }\end{array}$}} & \multicolumn{2}{|c|}{$\begin{array}{l}\text { mothers memory } \\
\text { not in accordance } \\
\text { with the records }\end{array}$} \\
\hline & & & & $\begin{array}{l}※ ※ \\
\text { earlier }\end{array}$ & later \\
\hline Holds head & 59 & 33 & $55.9^{9 /}$ & 8 & 18 \\
\hline Walks alone & 59 & 28 & 47.5 & 11 & 20 \\
\hline $\begin{array}{l}\text { Stretches arms } \\
\text { and grasps }\end{array}$ & 0 & 一 & - & - & - \\
\hline $\begin{array}{l}\text { Expresses } \\
\text { recognition of persons }\end{array}$ & 4 & 0 & - & 4 & 0 \\
\hline Sits alone & 38 & 16 & 42.1 & 14 & 8 \\
\hline Smiles & 28 & 13 & 46.4 & 0 & 15 \\
\hline Says one word & 2 & 1 & 50.0 & 0 & 1 \\
\hline
\end{tabular}

※ $\mathrm{B} / \mathrm{A}:$ coincident ratio

The mark $\% ※$ means that the episode is recorded to be done earlier than the time memorized by mother

Tab.16 Relationship between mother's memory and records in the booklet of birth-weight

\begin{tabular}{|c|c|c|c|c|c|c|c|c|}
\hline Location & $\begin{array}{l}\text { No. of } \\
\text { answers } \\
\text { (A) }\end{array}$ & \multicolumn{2}{|c|}{$\begin{array}{l}\text { with } \\
\text { memory } \\
\text { (B) }\end{array}$} & \multicolumn{2}{|c|}{$\begin{array}{l}\text { without } \\
\text { memory } \\
\text { (C) }\end{array}$} & $\begin{array}{l}\text { No. of records } \\
\text { in the booklets } \\
\text { (D) }\end{array}$ & $\begin{array}{l}\text { No. of moth- } \\
\text { ers memory } \\
\text { in accord- } \\
\text { ance with the } \\
\text { records (E) }\end{array}$ & $\begin{array}{c}\text { coincident } \\
\text { ratio } \\
(\mathrm{E} / \mathrm{D})\end{array}$ \\
\hline$y-$ town & 107 & 92 & $\therefore 86.0^{\% 6}$ & 15 & $\begin{array}{c}* * \\
14.0\end{array}$ & 87 & 67 & $77.0^{\text {\% }}$ \\
\hline $\mathrm{n}$-town & 49 & 47 & 95.9 & 2 & 4.1 & 28 & 19 & 67.9 \\
\hline $\mathrm{k}$-town & 26 & 24 & 92.3 & 2 & 7.7 & 10 & 6 & 60.0 \\
\hline$y$-village & 18 & 13 & 72.2 & 5 & 27.8 & 13 & 9 & 69.2 \\
\hline c-town & 33 & 28 & 84.8 & 5 & 15.2 & 25 & 16 & 64.0 \\
\hline $\mathrm{m}$-village & 33 & 21 & 63.6 & 12 & 36.4 & 20 & 11 & 55.0 \\
\hline Total & 266 & 225 & 84.6 & 41 & 15.4 & 183 & 128 & 69.9 \\
\hline
\end{tabular}

$※ \mathrm{~B} / \mathrm{A} \times 100, ※ \circledast^{\mathrm{C}} / \mathrm{A} \times 100$

Tab.17 Mother's evaluation of her child's body growth

\begin{tabular}{|c|c|c|c|c|c|c|c|c|}
\hline & . & $\begin{array}{c}\text { Comprehensive } \\
\text { evaluation } \\
\text { (A) }\end{array}$ & & & & & \multicolumn{2}{|c|}{$\begin{array}{l}\text { ze of } \\
\text { chest } \\
\text { (D) }\end{array}$} \\
\hline \multirow{2}{*}{$\begin{array}{l}\text { Mother's } \\
\text { evaluation }\end{array}$} & large & 175 & 163 & $93.1^{\%}$ & 142 & 81.1 & 126 & 72.0 \\
\hline & small & 221 & 202 & 91.4 & 180 & 81.5 & 163 & 73.8 \\
\hline
\end{tabular}


重, 胸囲の三項目の判定と合わせて綜合判定を行なった ところ表17に示すどとく, 綜合判定以当たっては, 母親 は身長を重視していることが認められた。とれら母親の 子供の成長, 発育に対する判定根拠は決して科学的なあ のとはいえず, 母子健康手帳の活用によって, 今後, 単 に身体発育のみならず, 情緒面, 精神面についてす, 正 しく子供の発育，発達を評価し得るよう管理することが 期待される。
V. 結 論

以上, 調査結果を検討してきたが, 下記 6 点にその結 論を要約し得る。

1）母子手帳の保存は小学校 1 学年時においても良い。

2）母子手帳の記載状況は出産 (分娩) を中心とした 記載は良いが，母親の自主的な記入は悪い。

3）母子手帳の有効な活用がなされていないととが,

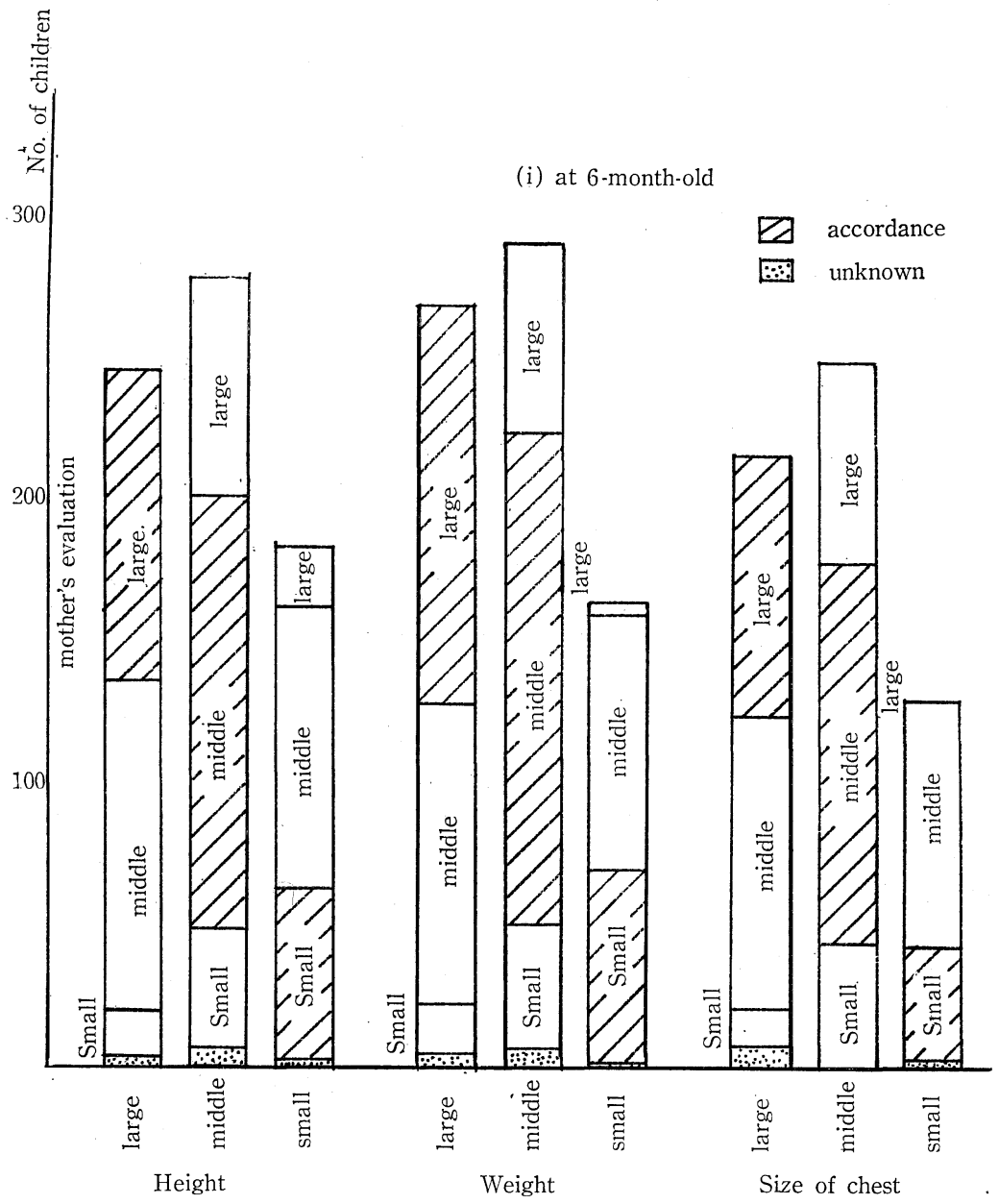

Standards of governmental statistics

Fig. 6 Relationship between mother's evaluation and governmental statistical standard upon body growth among children. 


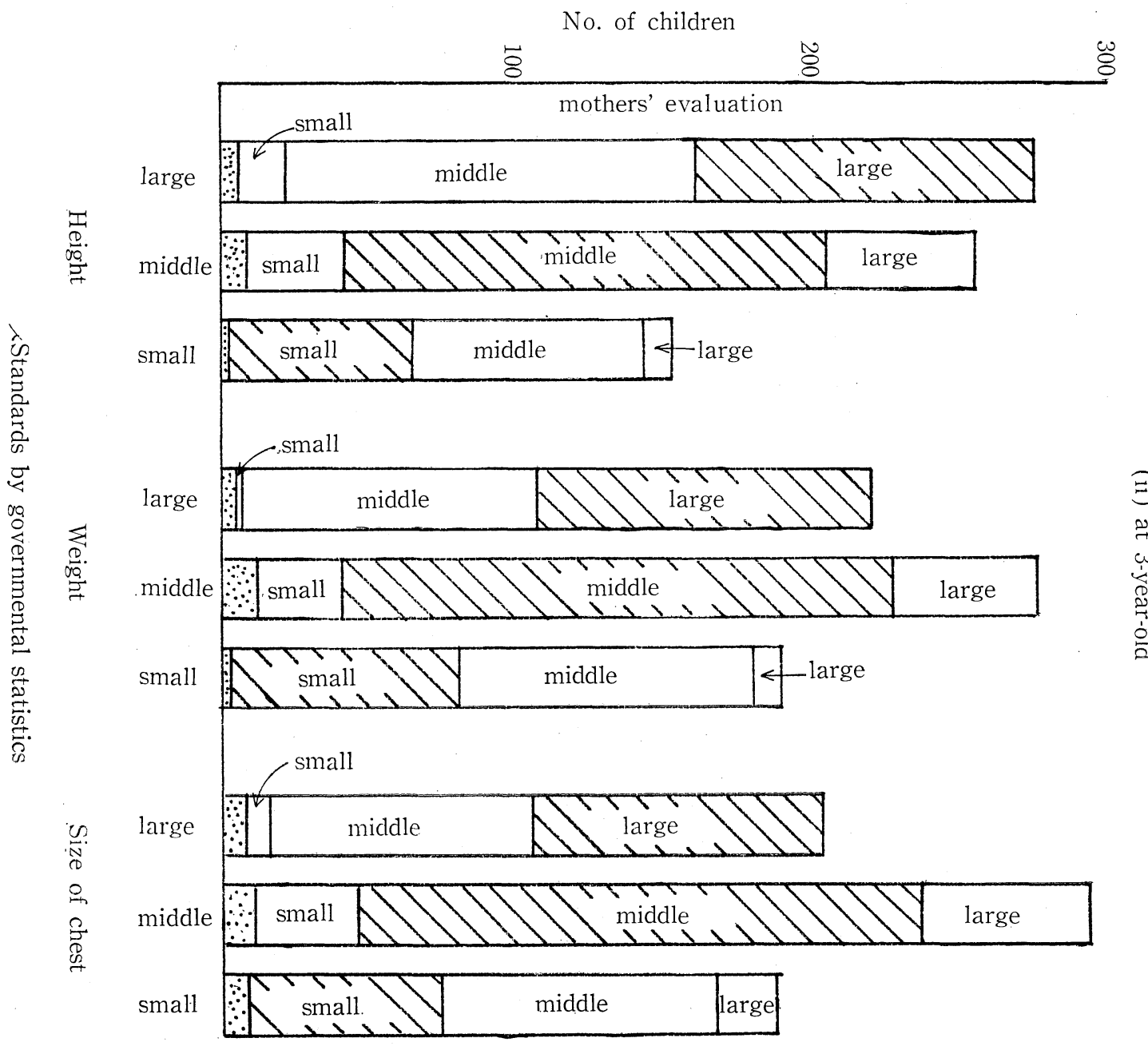

Fig. 7 Relationship between mother's evaluation and governmental statistical standard upon body growth among children 


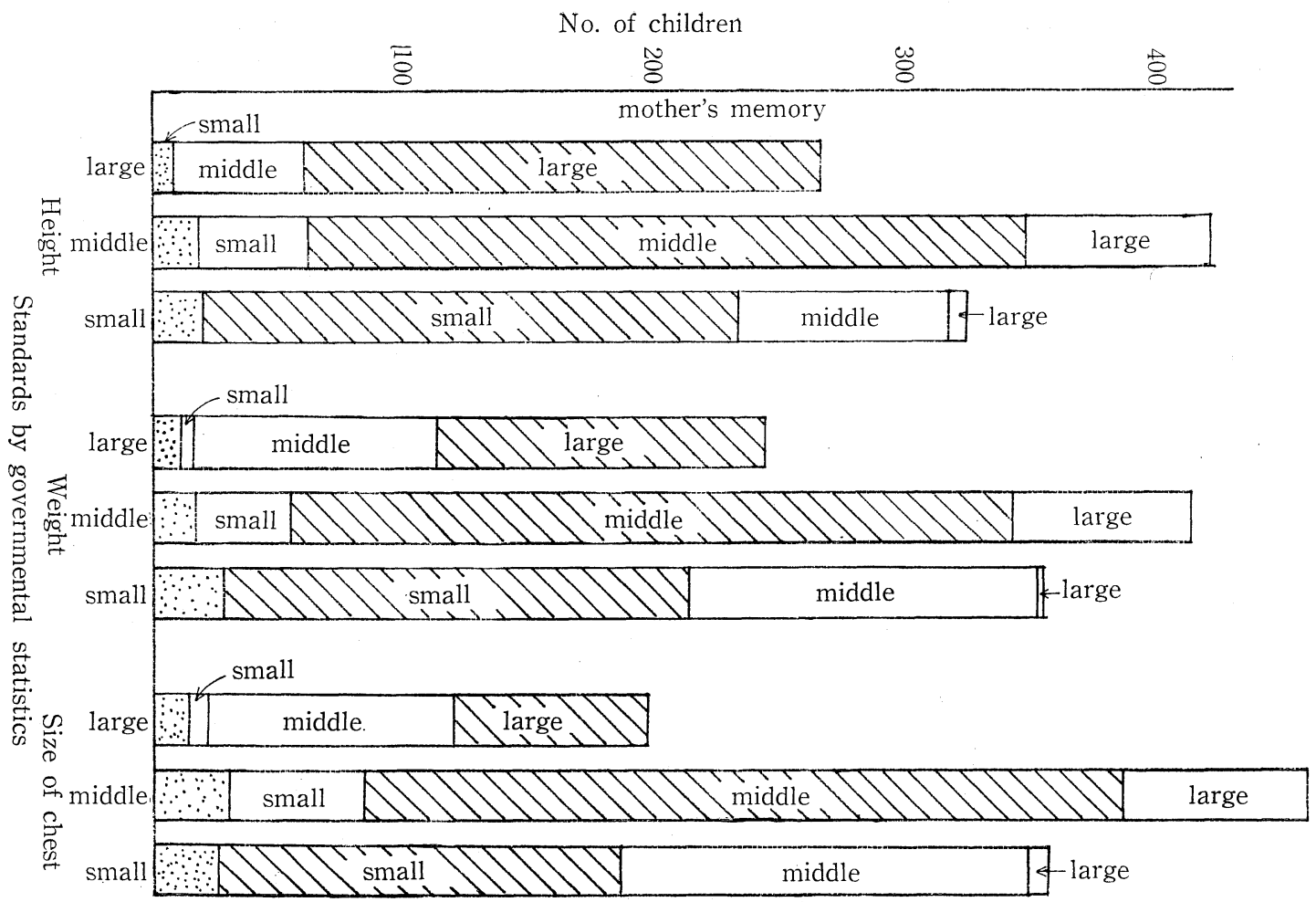

Fig. 8 Relationship between mother's evaluation and governmental statistical standard upon body growth

(ii) at first grade in primary school 


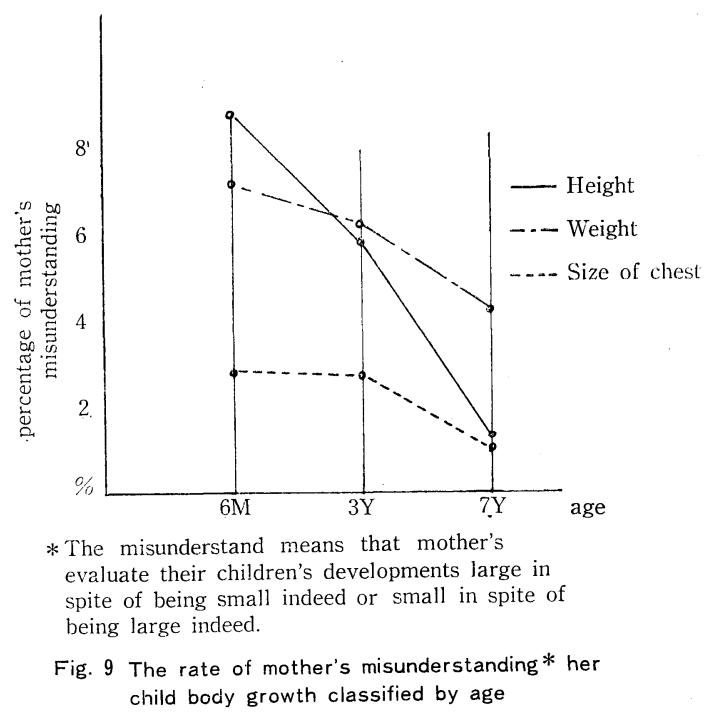

第 2 子以下の保存率を贯くしている。

4）目子 (健康) 手帳の活用の如何は, 受診医療機関 に対する母親の態度とこれら医療機関の母子 (健康) 手 悵に対する態度によって影響される。

5）母親の妊娠中の検猃についての記憶および子供の 成長についての記憶は可成り不正確である。

6）母親は子供の発育について不安を感じているが, それについての記録は充分でなく, 従って母親の子供の 発育に対する判定も誤りがあり, 特に発育小のあのにそ れが著明に認められた。

母子健康手帳は母子保健管理上の一手段として, わが 国に特有なあのであるにあかかわらず，その活用は充分 でなく, 以上に指摘し得た問題点を解決しつつ, その積 極的な活用をはかるならば，その有効性は非常に大きい といえる。

稿を終えるに当たり, 終始御指導, 御校閲いただいた 恩師大平昌彦教授, 青山英康講師に深甚の謝意を表しま す。な打本研究に当たって調査に御協力いただいた保健 所および学校の職員の方々に心から謝意を表します。

（な打本論文の要旨は第24回日本公衆衛生学会総会お よび第14回日本小児保健学会において発表した。）

文 献

1）厚生省医務局: 医制八十年史, 印刷局朝陽会, 東京 (1955).
2) 日本公衆衛生協会編 : 衛生行政大要 (改訂第 6 版), p. 161, 日本公衆衛生協会, 東京 (1969).

3）中沢幸一：わが国の母子保健の現状と対策, 厚生の 指標, 16(5), 30-35 (1969).

4）握美節夫 : 母子保健行政の問題点, 小児科診療, 32, 395-401 (1969).

5）母:子保健対策懇話会：母子保健綜合対策の確立に関 する意見書, 小児保健研究，26，138-145 (1968).

6) 中央览童福祉審議会 : 当面推進すべき母子保健対策 に関する意見具申，小児保健研究，26，292-296 (1969).

7）須川豊：母子保健管理をすすめるには, 公衆衛生, 32 (5), 2-3 (1968).

8) 林路彰: 乳幼児健康管理, 厚生の指標, 16 (5), 2529 (1969).

9) 宇留野勝正 : 乳幼児保健管理の諸問題, 小児科, 9 , 576-581 (1968).

10）石川淳一：地域社会における母子保健活動の方策之 そのあり方，小児科診療，32，402-407 (1968).

11）瀬木三雄 : 母子保健, 家族計画に注文する(2)母子健 康手帳, 家族計画, 第159号, 6 (1968).

12) 瀬木三雄：母子衛生行政之保健指導 (第 2 版), 医 学書院, 東京 (1956).

13）若月俊一，他：健康手帳による健康管理（第 7 報） 日農村医誌, 15, 189-191 (1968).

14）永田丕, 他：健康手帳による健康管理（第 1 報の1一 2 部), 日農村医誌, 15, 191-193 (1968).

15）白戸三郎：小学校児童の心身の保健管理, 健康教室 増刊号, 1-15 (1966).

16) 林邦雄 : 健康手帳をめぐる諸問題, 学校保健研究, 6 (9), 36-40 (1964).

17) 林路彰：母子衛生概説, 光生館, 東京 (1969).

18）浅野一雄：母性衛生, 公衆衛生活動ハンドブック, p. 660-661, 技報堂, 東京 (1960).

19）松島富之助：乳幼児保健指導および管理，現代小児 科学大系 18, p. 64, 中山書店, 東京 (1967).

20）榎戸ふみ，他：母子手悵利用に関する調査，母性衛 生, 6 (1), 18-21 (1965).

21）大塚昭二：育児日記の調査, 小児保健研究， 23，43 (1965).

22）厚生省：母子保健実態調查結果報告速報, p. 25-26, 厚生省児童家庭局, 東京 (1969).

23）杉原正造, 他 : 分娩後母子手帳交付を受けた家庭に ついての調査, 母性衛生, 6 (2), 11-13 (1965).

24）船川幡夫, 他: 昭和35年度わが国の乳幼児の身体発 育状態について，小児保健研究，21，19-25 (1962).

25) 文部省 : 学校保健統計調査報告書（昭和 40 年度） p. 38-39, 大蔵省印刷局, 東京 (1966).

（受付1970年 3 月19日） 